\title{
合成水酸化アパタイトのラット顎骨補埧時における病理組織学的研究
}

\author{
永井教之・竹下信 義・白須賀英樹・秋場 道 保
}

\section{Histopathological studies of implantation of hydroxyapatite in the rat jaw bone}

\author{
Noriyuki Nagai $\cdot$ Nobuyoshi Takeshita $\cdot$ Hideki Shirasuga $\cdot$ Michiyasu Akiba
}

\begin{abstract}
This study was performed to examine the osteogenesis-inducing capacity of hydroxyapatite (HAP) with non-sintering or sintering condition. Three HAPs, Undrying slurry HAP, drying $\mathrm{HAP}$ at $200^{\circ} \mathrm{C}$ and sintering $\mathrm{HAP}$ at $800^{\circ} \mathrm{C}$, were used. Each HAP was filled into an osseous cavity prepared in the rat mandible. Observation periods were 3 days, $1,3,8$ and 12 weeks after the filling of each HAP into the osseous cavity.

Histologic sections showed osteogenesis around each HAP particle. Each HAP particle was embedded in the new bone unlike tricalcium phosphate. Also, it was difficult to determine the difference of osteogenesis between each HAP.

In early periods of HAP filling, macrophages or multinuclear giant cells phagocytized HAP micro-particles. Thus, this study indicated that HAP had osteogenesis-inducing capacity which was not affected by sintering conditions in the synthesis process of HAP. We also proposed that the particle size of HAP had to be larger than the size of the particle phagocytized by phagocytic cells for the inducer of osteogenesis.
\end{abstract}

Key words: hydroxyapatite, sintering condition, osteogenesis

緒言

近年, 合成ハイドロキシアパタイト (HAP) は骨補填 材や人工歯根として, 生体材料の重要な位置を占めてい る. 合成ハイドロキシアパタイトの骨補填材応用に関し て, 多くの臨床的, 実験的研究が行われ, HAP が骨形 成を誘導することが示されている ${ }^{1 \sim 5)}$ 。た，HAP は生 成条件, 特に焼成温度により化学的, 物理的性質に差異 が生じることも知られている3,6,7). 現在までに報告され た HAP の骨埋入実験に使用された HAP は，高温焼成 $\left(900 \sim 1,200^{\circ} \mathrm{C}\right)$ であることが多い. 非乾燥状態 ( ラリー) を含め種々の焼成温度で生成された HAP に対 する骨組織の生物学的反応は全く知られていない，われ われは, スラリーを初め焼結温度の異なる数種類の HAP

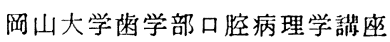

（主任：永井教之教授）

Department of Oral Pathology, Okayama University School of Dentistry (Chief: Prof. Noriyuki Nagai)

受付日：昭和60年 1 月 24 日
を人工的䫇骨欠損部に埋入し，新生骨形成過程を組織学 的に検索した。

\section{材料および方法}

実験動物は雄 Wister ラット（体重：200 g）40匹であ る. 使用した HAP は湿式法により合成（太平化学産業 研究部）されたものであり，(1) 合成直後のスラリー (S-HAP ; HAP $30 \%$ 含有), (2) 合成後 $200^{\circ} \mathrm{C}$ 乾燥し たもの (2-HAP)，および（3）合成後 $800^{\circ} \mathrm{C}$ 狫成した もの (8-HAP) の 3 種類である。また，2-，8-HAP は 乾燥または焼成後, 粉砕して粉末状としたものであり, 粒径は各 HAP とも 0.5〜40 $\mu \mathrm{m}$ である.

動物を腹腔内麻酔して，下顎骨下縁に沿って皮雐に切 開を加え，十分に骨面を露出し，歯科用ラウンドバー （\#2）により $2 \times 1.5 \times 1.5 \mathrm{~mm}$ の简洞形成を行った。窝 洞内を隇菌生食水で十分に洗淮し，各 HAP を窩洞に填 入後筋組織掞よび皮膚を繾合した。観察期間はHAP 埋 入後 3 日，1，3，8および12週間である. 次に観察期間 に従って動物を $2 \%$ グルタールアルデヒト・ $2 \%$ バラホ ルムアルデヒド固定液により灌流固定して，下顎骨を摘 
出した，摘出した下顎骨を $10 \%$ EDTA 液で脱灰後，常 法に従ってパラフィン包埋し， $4 \mu \mathrm{m}$ パラフィン切片を 作製した。また，パラフィン切片にはへマトキシリン・ エオシンン染色を施して, 光䫓的に観察を行った.

\section{結果}

\section{S-HAP}

埋入 3 日目: S-HAP 粒子間隙には, 好中球浸潤, フ ィブリンの析出および赤血球が混在している。 また窝洞 底部より,リンハ球, マクロファージ，線維芽細胞に富 んだ肉芽組織が増殖している。この肉芽組織内では, S-HAP 微小粒子を食食したマクロファージが認められ， 粒径 $20 \mu \mathrm{m}$ 以上の S-HAP 粒子は類円形, 紡鍾形細胞 によって包囲されている（写真 1 ）.

埋入 1 週間 : 線維芽細胞の豊富な肉芽組織が, S-HAP 粒子間隙を充満して増殖し，S-HAP 粒子に接して類円 形細胞が認められる。炎症性細胞浸潤は認められない。 また窩洞底部より梁状 Callus 形成が羿められ，一部の Callus には，S-HAP 粒子が埋入されている（写真 2). これら Callus 表面には多数の骨芽細胞が配列し，また， Callus 間の線維性組織には, S-HAP 微小粒子を貪食し たマクロファージが散見される。

埋入 3 週間: 種々の太さの Callus が S-HAP を包埋 して著明に增生している. Callus 周囲には多数の骨芽細 胞か配列し，また，Callus 間隙には線維芽細胞に富んた 線維性組織が存在している (写真 3). Callus 内S-HAP 粒子と Callus 基質との境界は不明瞭である（写真 4).

埋入 8 週間 : 不規則な層板構造を有する緻密骨組織が 埋入简洞を完全に補填し, 骨組織内にはS-HAP 粒子が 包埋されている。また，骨組織には Haver’s 管腔および 骨髄腔も形成されている，S-HAP 粒子と骨組織との境 界は不明瞭であるが，時に粒子周縁にへマトキシリン好 性線が存在している（写真 5 ).

埋入 12 週間 : 埋入 8 週間と同様に, 大小不整なS-HAP 粒子は緻密, 層板骨組織によって包埋され, 粒子周縁に はへマトキシリン好性線が認められる（写真 6,7)。 た，骨組織内には，多数の骨細胞，Haver’s 管腔および 骨髄腔が存在し，S-HAP 粒子が細胞を介して骨髄腔と 接するところも観察される（写真 8 ).

\section{2-HAP}

埋入 3 日目: 埋入した 2-HAP 粒子間隙には, 好中球 浸潤,フィブリンの析出が認められ，窩洞底部よりリン ハ球, マクロファージおよび線維芽細胞などに富む肉芽 組織の増殖が認められる。肉芽組織内には, 2-HAP 微 小粒子を貪食したマクロファージ多核巨細胞が存在し,

また，2-HAP 粒子周囲には類円形細胞や，骨芽細胞様 細胞が認められる(写真 9 ).

埋入 1 週間 : 2-HAP 粒子間隙は, 線維芽細胞に富ん
た肉芽組織により満され，窩洞底部よりは，種々の太さ の梁状 Callus が新生している. 肉芽組織内では, 2-HAP 粒子に接した骨芽細胞様細胞が認められる。 また Callus 増生域では, Callus が 2-HAP 粒子を包囲するように新 生し，2-HAP 粒子を埋入した Callus も認められる（写 真10). Callus 周囲には多数の骨芽細胞が不規則に配列 している.

埋入 3 週間：埋入窩洞をほぼ補填するように, Callus が形成され, Callus 内には大小の 2-HAP 粒子が包埋さ れている(写真11)。また，Callus 間の狭い間隙には粗 な線維性組織が認められる。包埋された 2-HAP 粒子と Callus との境界は比較的不明膫であり, Callus が粒子 内に進入するように形成されているところも钼察される (写真12). Callus 周囲には, 多数の骨芽細胞が 配列し ている.

埋入 8 週間：2-HAP 粒子を包埋した，不規則な層板 構造を有する緻密骨組織が埋入窝洞を完全に補填してい る（写真13）。2-HAP 粒子と骨組織の境界にはへマトキ シリン好性線が認められるが，一部では 2-HAP 粒子は 骨組織との境界がきわめて不明瞭となっている（写真 14）、徵密骨組織は多数の骨細胞, Haver's 管腔扰よび 骨髄腔を含有している。

埋入12週間：2-HAP 粒子は徵密層板骨組織により包 埋され，両者の境界にはへマトキシリン好性線が認めら れる(写真15)。骨組織は多数の骨細胞, Haver's 管腔打 よび骨䯣腔を有しており，2-HAP 粒子が骨髄腔と接し ていないところも観察される（写真16）.

\section{8-HAP}

埋入 3 日目: 埋入した 8-HAP 間隙に, 好中球, 析出 フィブリンおよび赤血球が混在している，裔洞底部よ り，多数のマクロファージ，線維芽細胞を含有した肉芽 組織が增殖している。肉芽組織は 8-HAP 粒子を取り込 みながら増殖し，8-HAP 粒子は類円形，紡鍾形細胞に より包囲されている (写真17). 少数の8-HAP 粒子は骨 芽細胞様細胞によって囲まれている。 また，微小粒子は マクロファージや多核巨細胞によって貪食されている。

埋入 1 週間：肉芽組織が 8-HAP間隙を満して增殖し， 窩洞底部より Callus 新生が始っている。肉芽組織域で は, 8-HAP 粒子が多数の骨芽細胞様細胞や紡錘形細胞 によって册まれている。また，Callus 新生域では，8HAP 粒子は Callus と接するものや, Callus に埋入さ れたものなど多様であり, Callus 周囲には多数の骨芽細 胞が配列している（写真18）.

埋入 3 週間 : 8-HAP 粒子を包埋した Callus が窩洞全 体にわたり形成されている。狭小な Callus 間隙には線維 性組織が存在している（写真19）。また，8-HAP 粒子と Callus との境界は不明瞭で, Callus 表面には多数の骨芽 細胞が認められる(写真20).

埋入 8 週間 : 8-HAP 粒子を包埋した Callus は徽密成 
熟骨組織に完全に移行し，両者の境界には薄いへマトキ シリン好性層が認められる（写真21）。また，骨組織は 不規則な層板構造を有し，多数の骨細胞, Haver's 管腔 および骨䯣腔も認められる。

埋入12週間：8 週間と同様に 8-HAP 粒子は緻密層板 骨組織に包埋されている（写真 22，23）。 また，8-HAP 粒子が直接，骨䯣腔と接しているところも認められる (写真24).

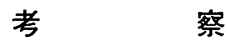

合成ハイドロキシアパタイト (HAP) はリン酸カルシ ウム系セラミックスのひとつであり, 三リン酸カルシウ ム (TCP) とともに生体材料として種々の生体内応用が 期待されている ${ }^{1212)}$. HAP は合成条件, 特に焼結温度 により異なった物理的, 化学的性質を示すことも知られ ている ${ }^{3,6,7)}$ 、すでに, 田端ら ${ }^{13)}$ は高温焼結して得られた HAP を人工歯根として実用化している. 一方, 骨補填材 の応用に関して，人工的骨欠損部へ HAPを補填して新 生骨形成を検討した実験的研究が行われている1 5,8 10)

これらの研究によると, 多孔質 $\mathrm{HAP}^{8)}$ あるいは粒状 $\mathrm{HAP}^{1 \sim 5,9,10)}$ のいずれにおいても，HAP が新生骨誘導能 を有することが示されている。 また，これらほとんどの 実験的研究は $900 \sim 1,300^{\circ} \mathrm{C}$ と高温焼結した HAP を使 用している。

われわれは HAP の生成条件, 特に焼成温度の差と骨 誘導との関連性の有無について検討した結果, 1 週間目 でいずれの状態の HAP \& HAP 粒子を埋入しながら幼 若骨組織形成が開始されていた。 また，S-HAP でも幼 若骨組織形成に先立って，HAP 粒子が骨芽細胞様細胞 により取り囲まれていたことを考え合せると，本材料の 場合どのような焼結状態であっても，HAP が骨形成の核 となり，骨誘導能を有することが示唆された。このこと から, HAP の骨誘導能は HAP の基本的性質であり, 焼 結温度によって影響を受けないことが示唆された. HAP の骨誘導能機構について不明の点が多い. HAP 表面が 微量溶解することによる化学的刺激といら考え方もある $か^{6}$ )，Ca イオンの局所的濃度上昇に成因があるとすれ ば, 溶解性の高いスラリーや $200^{\circ} \mathrm{C}$ 乾燥粉末の周囲は 骨形成の条件が有利に展開している可能性があり, われ われは今後，この方向から研究していく必要がある.

先にわれわれは，HAP を皮下移植実験の結果，HAP 粒子は大きさにより，また経時的にマクロファージ，多 核巨細胞による貪食や線維性組織による被包化を受ける ことを明らかにしたが，それらは生体の基本的な防御反 応のひとつと考えられている，本実験において，HAP の骨埋入初期においては，いずれの HAP においてもマ クロファージや多核巨紐胞が HAP 微小粒子を貪食して いたが，大型粒子は貪食されることなく，新生幼弱骨が
その表面に添加され，最終的に成熟骨に包埋されてい た，HAP が骨補填材となるためにはその粒径が，貪食 細胞や多核巨細胞に貪食されない以上の大きさが必要と 考えられる。

HAP と同じリン酸カルシウム系セラミックである三 リン酸カルシウム (TCP) は骨埋入され, 溶解, 消失し ながら新生骨と固換する14,15)。これに対して，HAPは， 本央験でも示したように，ほとんど溶解，消失せず，新 生骨組織に包埋, 残留していた。 HAP は Bioactive セ ラミックとして，TCP は Biodegradable セラミックと して位置付されているが，骨補填材として，HAP, TCP のいずれを選択するかは，今後さらに詳細な研究を重ね る必要があると思われる。

\section{結論}

われわれは, 生成条件, 特に焼成温度の異なる 3 種類 の合成ハイドロキシアパタイト (HAP)， S-HAP，2HAP, 8-HAP をラット下顎骨に埋入し, 新生骨誘導に ついて組織学的に比較, 検討して, 以下の結論を得た.

1. いずれの HAP 埋入でも, 埋入 3 日から 1 週間で, HAP 微小粒子を貪食するマクロファージや多核巨細胞 が出現していた。

2. HAP 粒子に接して Callus 形成が開始し, いずれ の HAP も同程度の骨誘導能を有することが確認され た.

3. 各 HAP 埋入後の Callus 形成時期, 新生骨成熟期 にほとんど差異がなく, HAP 埋入後の骨形成過程の組 織学的推移に, 焼成温度は影響しないことが明らかとな った.

4. HAP が骨誘導能を発現するためには，マクロ ファージ，多核巨細胞に貪食されない粒径の大きさが必 要であることが示唆された。

\section{引用 文 献}

1）永井教之・セラミック・宷科インプラントの病 理学的アプローチ. 東京菌科医師会婎誌 39: 316-323 1984.

2）高桥 忍, 丹羽滋郎, 他 : 人工移植骨材として の合成水酸アパタイト.医学のあゆみ116:1561571981.

3) 原 宜興, 古川猛士, 他：リン酸カルシウム系 セラミックの宷周治療への応用 1. Hydroxyapatite についての基礎実験. 日菌周誌 25:8068161983.

4）鴨井久一, 那波明夫, 他：料周治療における骨 移植の研究. 第 2 報 Hydroxyapatite のマイク ロラジオグラフィ扰よび病理組織学的矿究. 日 橉周誌 26: 523-531 1984 . 
5）渡辺英弥，青木宏道，他：リン酸カルシウム系 セラミックの歯内療法領域への応用に関する基 礎的検討 (第 1 報)。特にハイドロキシアパタ イト系材品 PeriografTM について。速科学報 84: 1175-1183 1984.

6）青木秀希，加藤一男，他：新しい粎科インプラ ント材料としてのアパタイト狫結体。菌界展望 49: 567-575 1977.

7）鴨井久一, 米山武義, 他：芼周治療に扣ける骨 移植の研究. 第 1 報 Hydroxyapatite の基礎的 研究. 日崡周誌 26: 275-288 1984.

8）山崎安晴：人工骨としての多孔質アパタイト 一顎骨補填央験—— 口病誌 51：372-406 1984.

9）林 成忠, 木村喜保, 他：サル宷槽骨欠損部に おける Hydroxyapatite 移植の臨床的および組 織学的研究. 日歯周誌 25: 919-935 1983.

10）原 宜興, 岸哲也, 他：リン酸カルシウム系 七ラミックの菌周治療への応用. 3. 実験的菌 周炎への Hydroxyapatite の応用. 日歯周誌 26: 542-555 1984.

11）中川寛一：粕内療法領域における生体材料の応
用に関する臨床病理学的研究. 特にハイドロキ シアパタイトの応用価値に関する検討。歯科学 報 83：501-527 1983.

12) 庄司茂, 石川潤一, 他：多孔質ハイドロキシ フパタイトの荬内療法への応用。1. 根管充填 材として。 日菻保誌 27：658-667 1984.

13）田端恒雄, 小木兽誠：アパタイトセラミックイ ンプラント. 歯科シャーナル 18: 337-348 1983.

14）永井教之, 丸山晴義, 他: 合成水酸化了ハタイ 卜粉末の皮下移植試験に関する基礎的研究。岡 山蔽誌 4: 57-65, 1985.

15) Bhaskar, S.N., Brady, J.M., et al.: Biodegradable ceramic implants in bone. Electron and light microscopic analysis. Oral Surg 32: 3363461971.

16) Jarcho, M.: Calcium phosphete ceramics as hard tissue prosthetics. Clin Orthop Res 157: 259-278 1981.

17）古川猛士, 岸哲也, 他：リン酸カルシウム系 セラミックの歯周組織への応用. 2. Tricalcium phosphate についての基礎実験。日歯周誌 26 : 263-274 1984. 


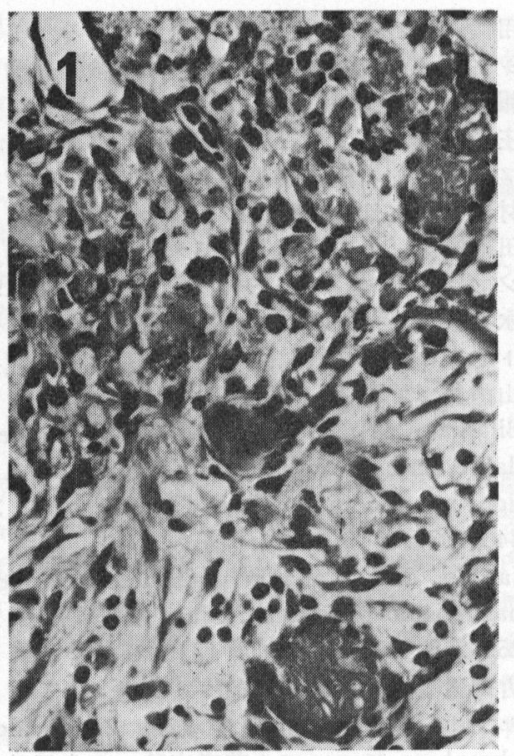

写真 1 HAP スラリー埋入 3 日目

(H-E, $\times 300)$

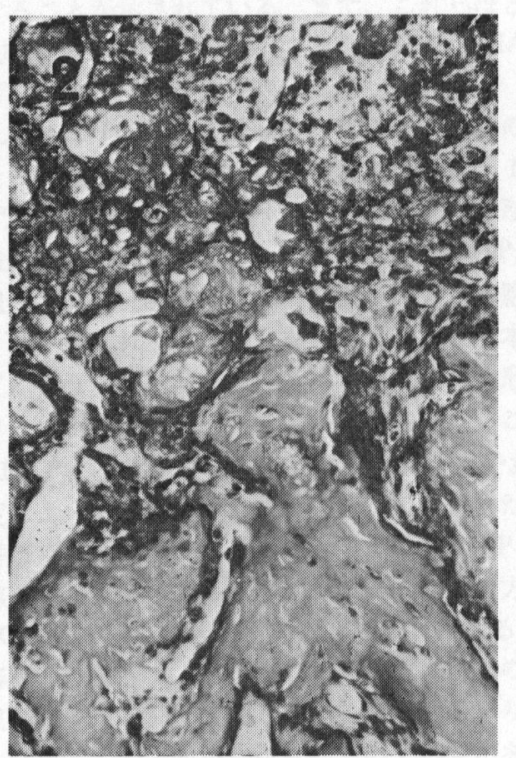

写真 2 HAP スラリー埋入 1 週目

(H-E, × 150)

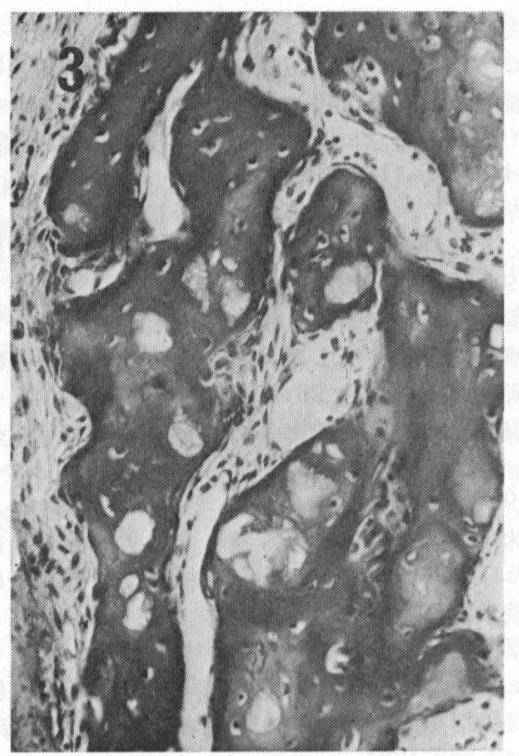

写真 3 HAP スラリー埋入 3 週目

$(\mathrm{H}-\mathrm{E}, \times 150)$

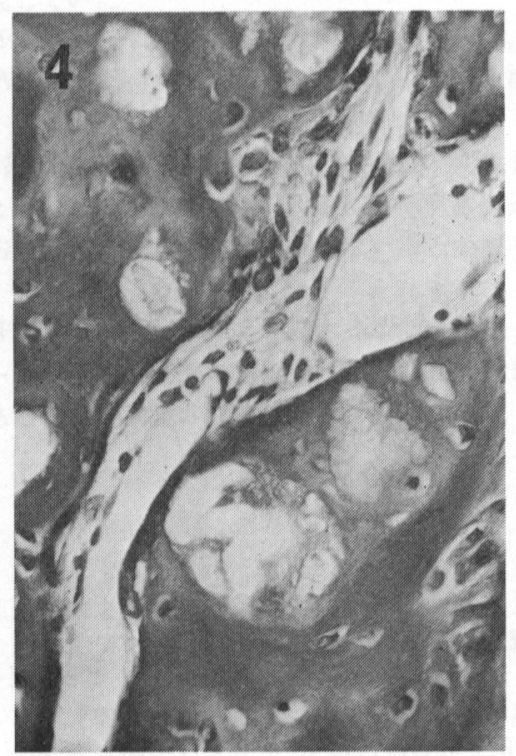

写真 4 HAP スラリー埋入 3 週目

$(\mathrm{H}-\mathrm{E}, \times 300)$ 


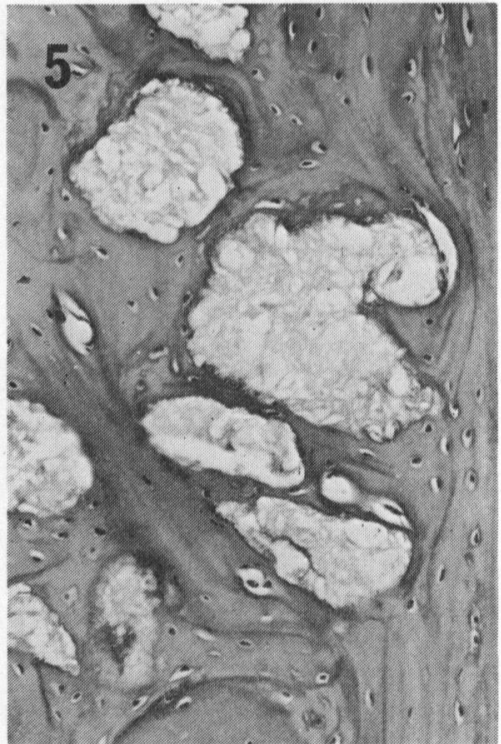

写真 5 HAP スラリー埋入 8 週目 $(\mathrm{H}-\mathrm{E}, \times 150)$

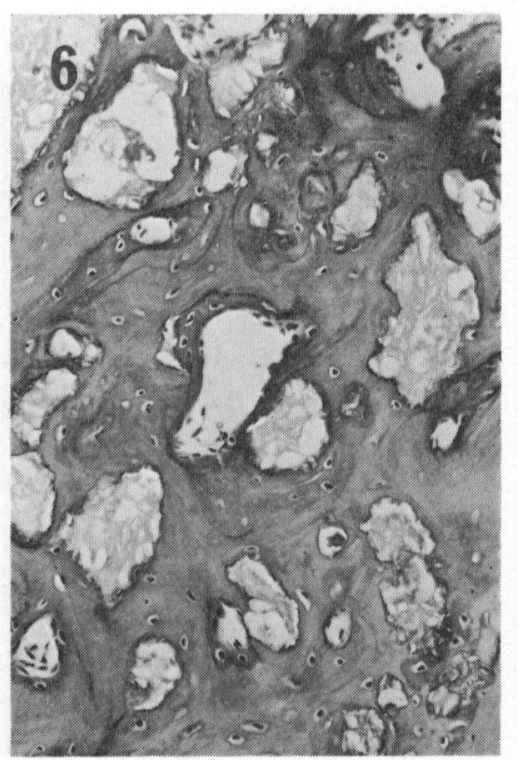

写真 6 HAP スラリー埋入 12 週目 $(\mathrm{H}-\mathrm{E}, \times 150)$

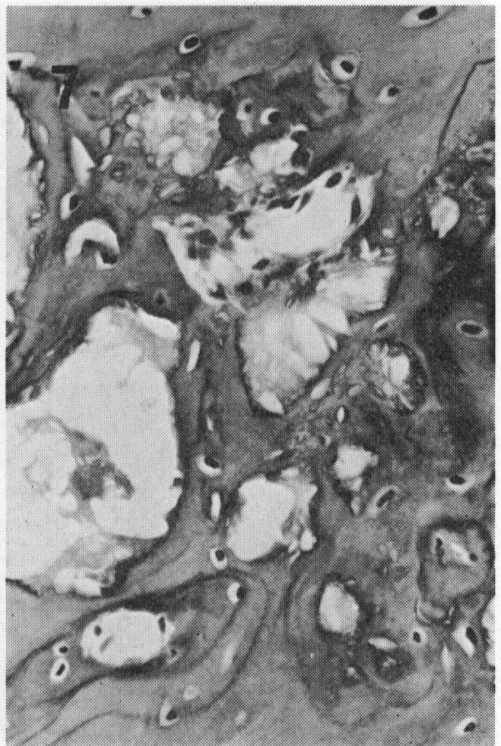

写真 7 HAP スラリー埋入 12 週目

(H-E, × 300)

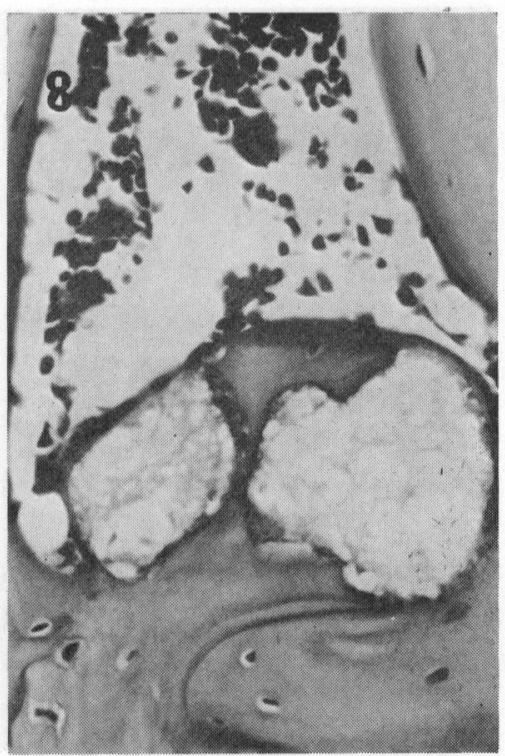

写真 8 HAP スラリー埋入 12 週目

(H-E, × 300) 


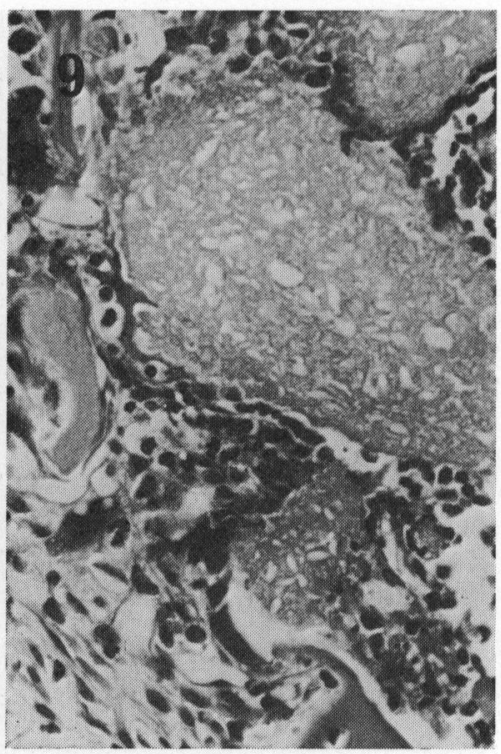

写真 $9200-\mathrm{HAP}$ 埋入 3 日目

$(\mathrm{H}-\mathrm{E}, \times 300)$

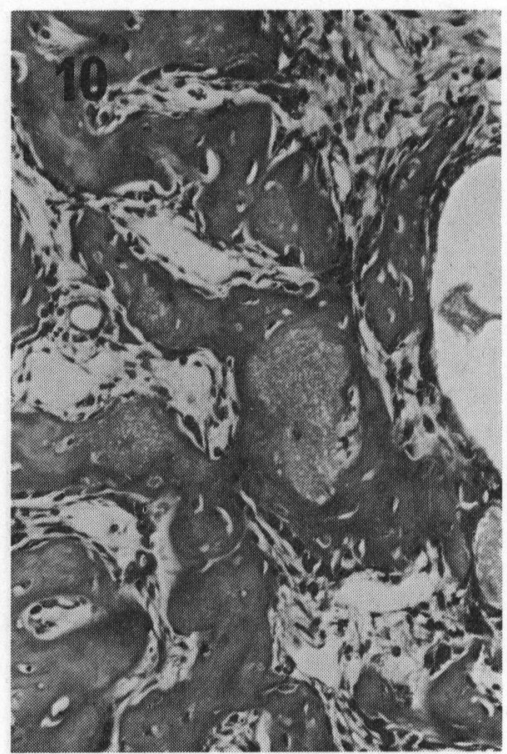

写真 $10200-\mathrm{HAP}$ 埋入 1 週目

$(\mathrm{H}-\mathrm{E}, \times 150)$

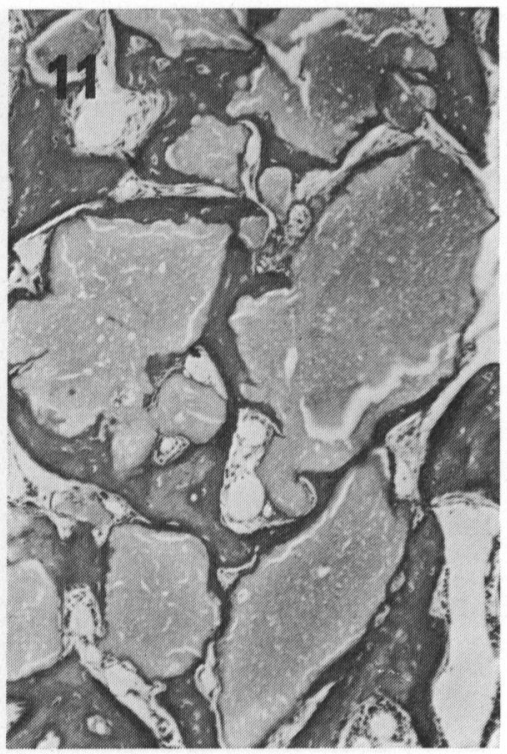

写真 $11200-H A P$ 埋入 3 週目

(H-E, $\times 77)$

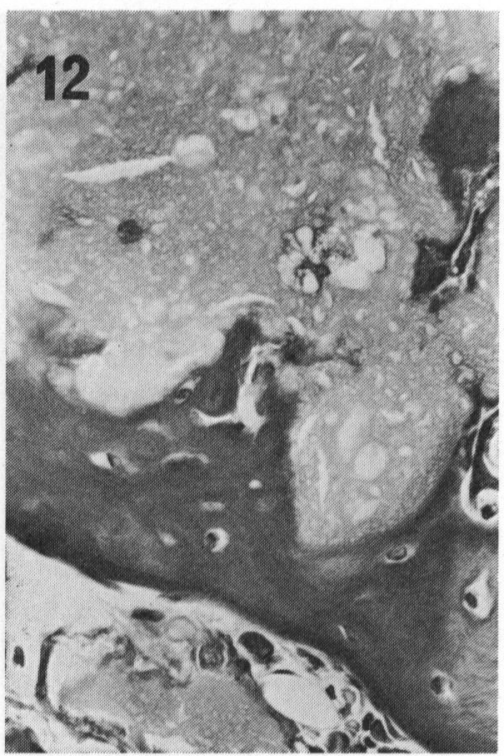

写真 12 200-HAP 埋入 3 週目

$(\mathrm{H}-\mathrm{E}, \times 300)$ 


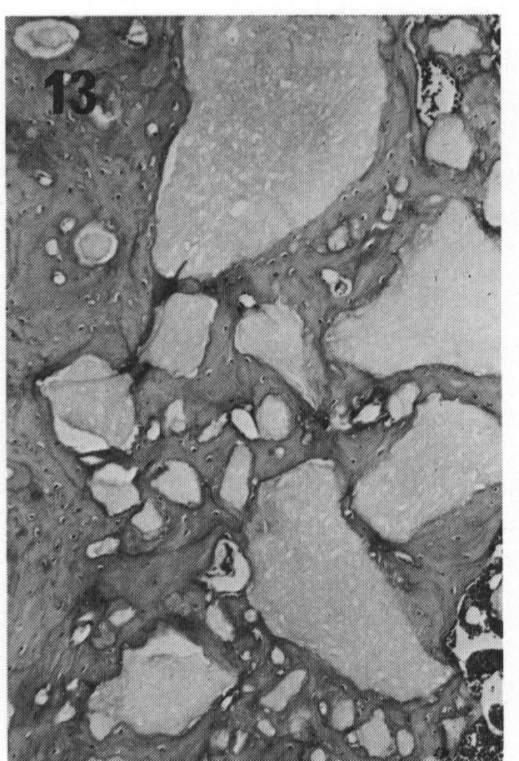

写真 13 200-HAP 埋大 8 週目

$(\mathrm{H}-\mathrm{E}, \times 77)$

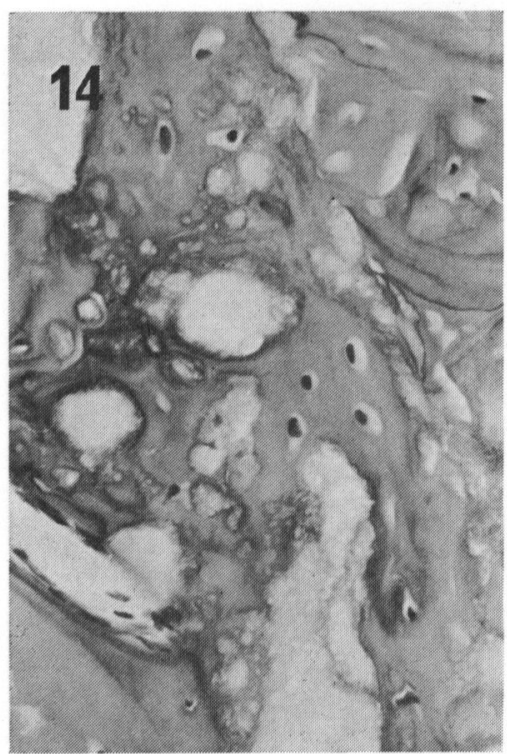

写真 14 200-HAP 埋入 8 週目 $(\mathrm{H}-\mathrm{E}, \times 300)$

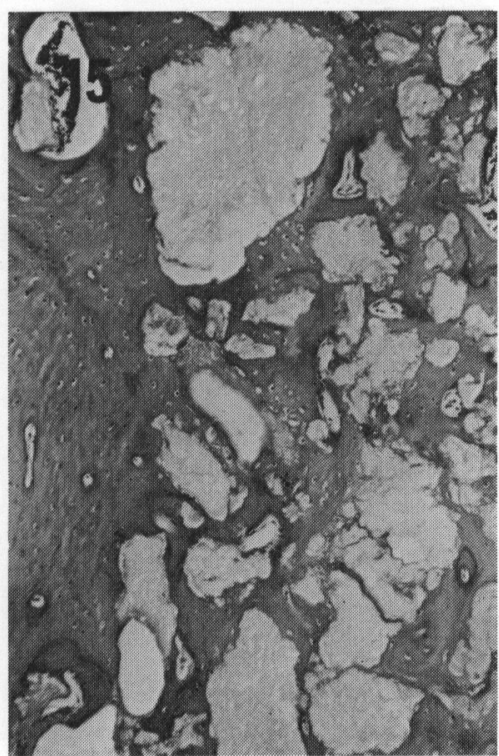

写真 $15200-H A P$ 埋大 12 週目

(H-E, $\times 77)$

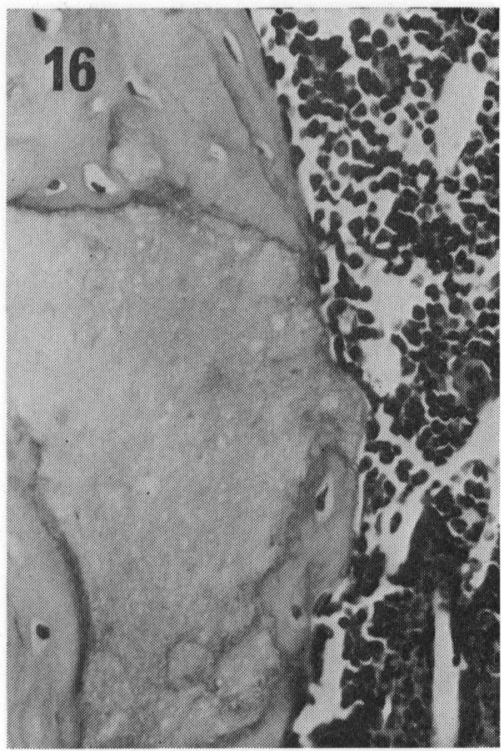

写真 $16200-H A P$ 埋入 12 週目

$(\mathrm{H}-\mathrm{E}, \times 300)$ 


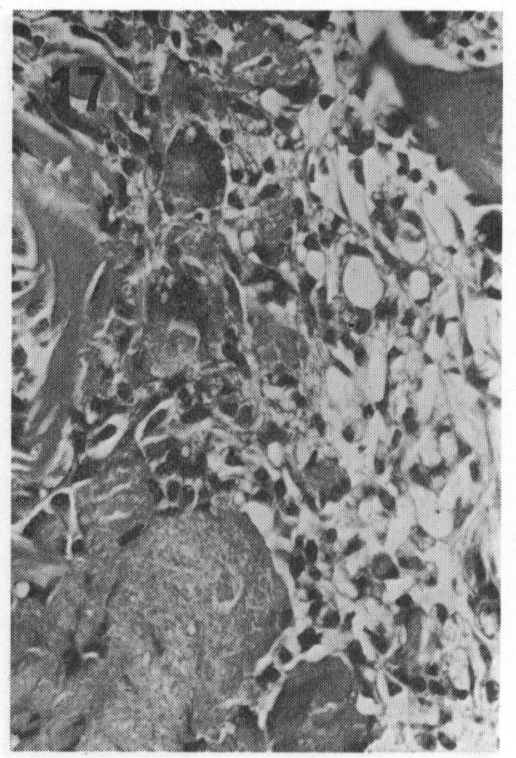

写真 $17800-H A P$ 埋入 3 日目

$(\mathrm{H}-\mathrm{E}, \times 300)$

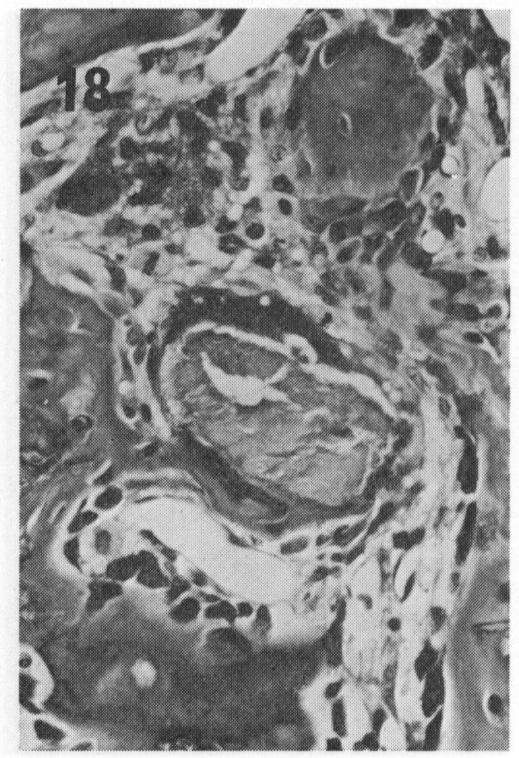

写真 18 800-HAP 埋入 1 週目 $(\mathrm{H}-\mathrm{E}, \times 300)$

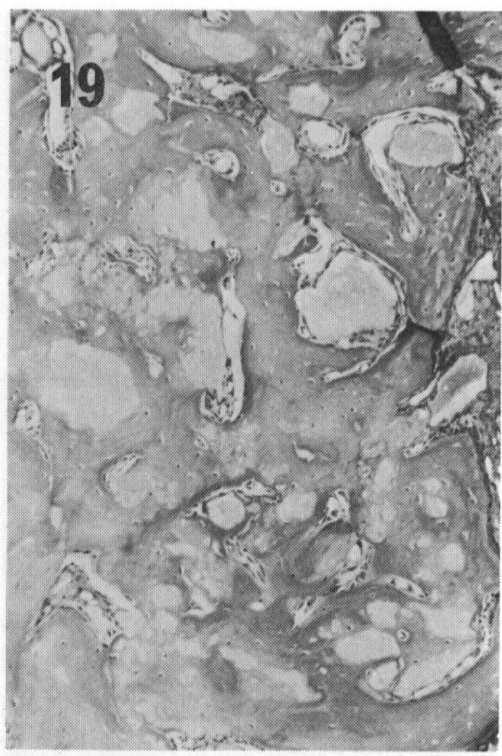

写真 $19800-H A P$ 埋入 3 週目

$(\mathrm{H}-\mathrm{E}, \times 77)$

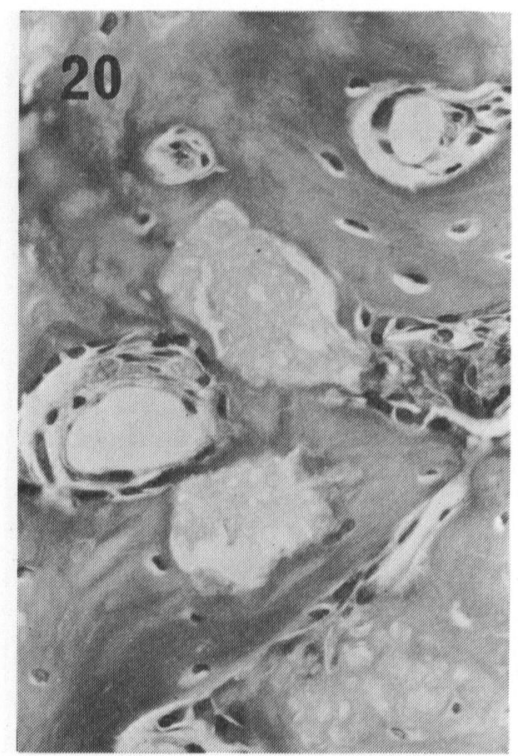

写真 $20800-H A P$ 埋入 3 週目

$(\mathrm{H}-\mathrm{E}, \times 300)$ 


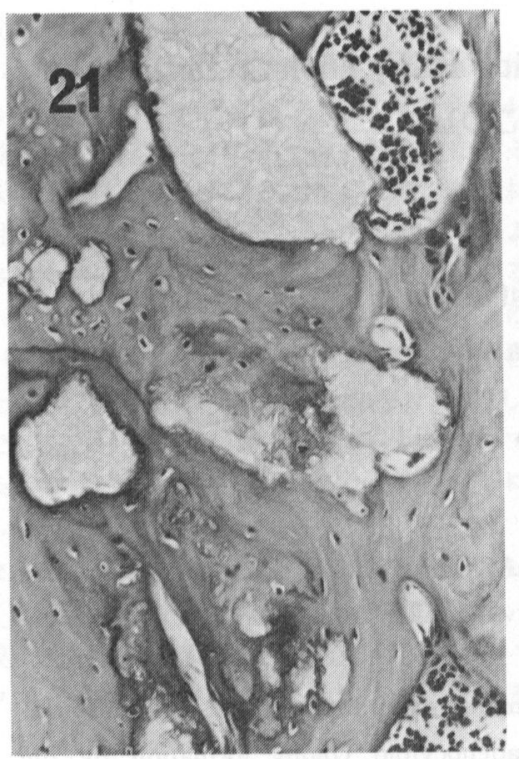

写真 $21800-$ HAP 埋入 8 週目 $(\mathrm{H}-\mathrm{E}, \times 150)$

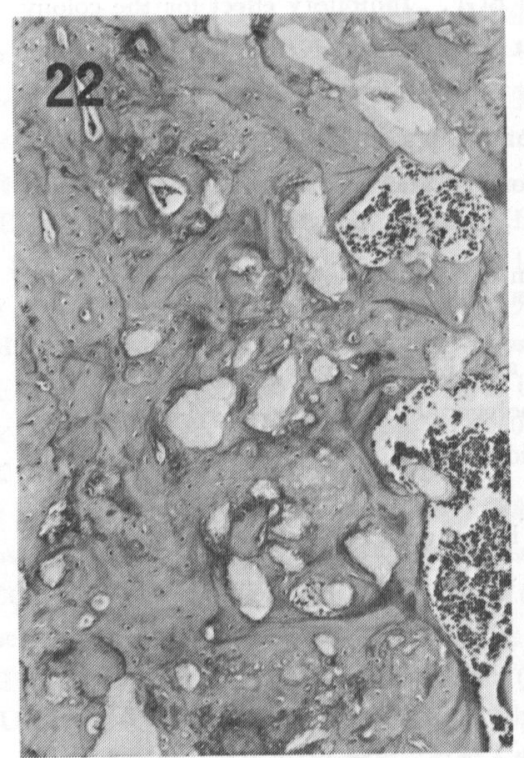

写真 $22800-\mathrm{HAP}$ 埋入 12 週目 $(\mathrm{H}-\mathrm{E}, \times 77)$

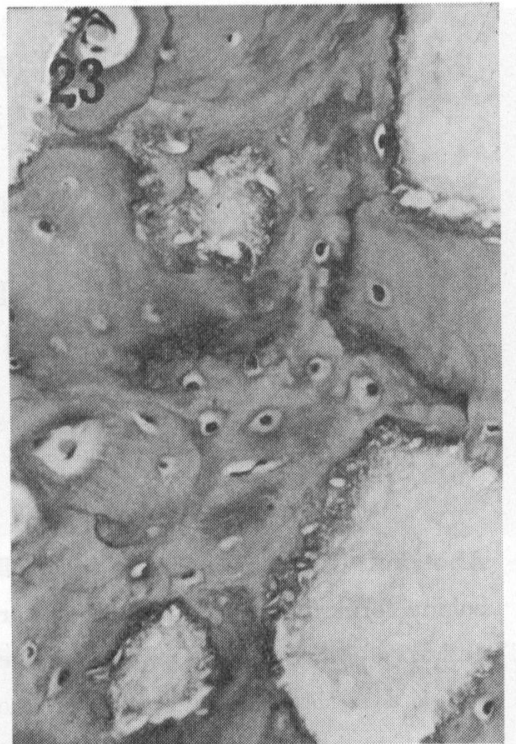

写真 $23800-\mathrm{HAP}$ 埋入 12 週目 $(\mathrm{H}-\mathrm{E}, \times 300)$

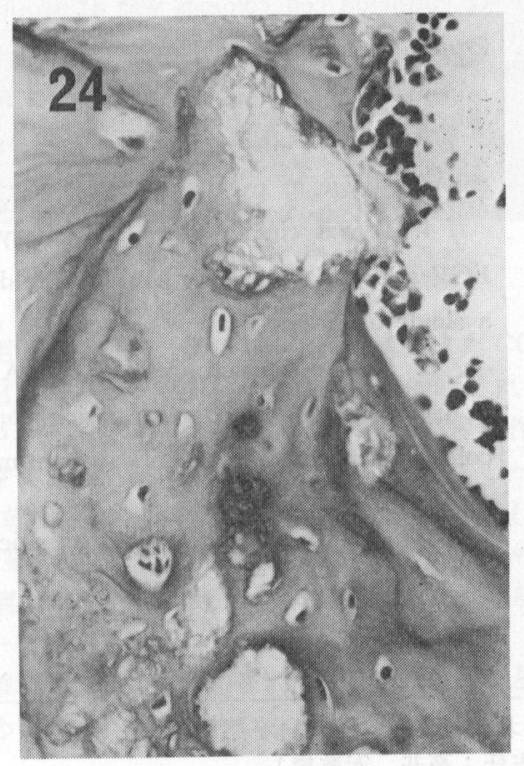

写真 $24800-H A P$ 埋入12週目 $(\mathrm{H}-\mathrm{E}, \times 300)$ 